\title{
Research on the internal teaching quality guarantee system of China-Germany cooperative education program
}

\author{
Dong Zhong \\ (School of electronic and information, Hubei University of Science and Technology, Xianning, Hubei \\ 437100, China) \\ email: zhongdong0129@163.com
}

Keywords: cooperative education; internal teaching quality; guarantee system

\begin{abstract}
The basic elements and realization path of the internal teaching quality guarantee system in China-Germany cooperative education program has been researched in this paper. And we improve the internal self-evaluation mechanism construction for China-Germany cooperative education program. It is great significance to improve the teaching level and teaching quality of China-Germany cooperative education program in our school.
\end{abstract}

\section{Introduction}

Internal teaching quality guarantee system which serve as the main strategy of sustainable development of China-Germany cooperative education program,is conducive for school to achieve the recurrent diagnosis of essential factor in teaching method and to impel the teaching quality to be improved continuously.It is conducive to achieve systematized management in teaching method and to form the system of comprehensive constraints and incentives .It's also conducive to protect students' interests and to improve the reputation of China-Germany cooperative education program. Internal teaching quality guarantee system is not only the necessary section of teaching in China-Germany cooperative education program, but also an important part .Even it is the basic of the whole teaching quality guarantee system of China-Germany cooperative education program.

\section{The basic elements of internal teaching quality guarantee system of China-Germany cooperative education program}

The education work is a systematic project. There are many complicated and various elements influencing teaching quality. In order to effectively guarantee the teaching quality, it should definitely figure out the elements that influence the teaching quality. Considering realistic situation of our teaching quality guarantee system of China-Germany cooperative education program, this paper makes a discussion on these elements to lay the foundation for sorting the basic ideas of teaching quality guarantee system out.

\subsection{Teacher factor}

Introducing foreign high quality education resources is the fundamental purpose of running the cooperative school, and digesting, absorbing, innovating and transforming the quality education resources of foreign countries is the only way to improve the quality of China and foreign cooperative education .Teachers is the key factor of quality educational resources. Actually, in many university teachers can't satisfy the teaching requirement in terms of quantity and quality. Even it seriously affect the quality of teaching.

\subsection{Students ' resources factor}

Quality of student source is one of the important factors of teaching quality to affect China-Germany cooperative education program. Students who choose the China-Germany cooperative education program means to face the challenge of multiculturalism and the solid foundational knowledge, a positive attitude and strong learning capability are the premise of meeting and responding to the challenge. The phenomenon that they enrolls students in a low marks 
leads to a bad quality of student source. However, the phenomenon limits the improvement of the level to run a school. The postgraduate education is not well developed which conversely influences the quality of source. Thus all of the elements form a vicious circle.

\subsection{Curriculum factor}

After investigate, the lessons of our teaching quality guarantee system of China-Germany cooperative education program are a little scattered and are lacking of the integrity design. The students are strengthening the language and seldom learning professional knowledge, Meanwhile, are lacking of localization. The internationalized talented persons trained by China-Germany cooperative education program are the own persons of China. They should have national consciousness, national consciousness and sense of responsibility. To achieve the aim ,China-Germany cooperative education program must innovate and transcend on the basis of reference.

\subsection{Teaching management factor}

By Cooperating with Germany school, our education program can draw on and introduce advanced teaching management experience and advanced teaching management system from them, and build an international teaching team. As the management object, the students and foreign teachers have their particularity and complexity, so the management of teaching also has the particularity and complexity.

\section{The basic path of the internal teaching quality guarantee system of China-Germany cooperative education program}

\subsection{Focus on cultivating innovative ideas and quality culture}

Cultivating innovative ideas is the forerunner of our teaching quality guarantee system of China-Germany cooperative education program. At present, China-Germany cooperative education program is insufficient and the foundation is weak. The fundamental cause is lacking of the motive force from the internal demand and development goal. It is more affected by external power .Lacking of ideas makes it difficult to form a long-term mechanism for internal teaching quality assurance. It should gradually make the cooperation between China-Germany scholars form a concept compatible with the internal teaching quality guarantee and take the initiative to bear the responsibility of ensuring the quality of teaching by theoretical research, policy and public opinion guidance.

\subsection{Emphasis assuring quality and pay attention to the participation of multiple subject}

Our internal teaching quality guarantee system of China-Germany cooperative education program needs to play its role. It should get the Identification, participation and support from multiply stakeholder. Firstly, teaching administrator should guarantee the construction of teaching management system, daily management, service, and auxiliary work. Secondly, as the practitioners and direct beneficiaries of the quality assurance measures, teachers and students should become the main power of the teaching quality guarantee.

\subsection{Reform the management system of teaching and build an innovative team}

The operation pattern of our China-Germany cooperative education program depends on School of electronics and Information Engineering and International College. In order to make full use of running a school with characteristics, the China-Germany cooperative education program should be built as a special teaching zone for reform and be given the autonomy in teaching quality guarantee system. School does well in the microscopical grasp and top-level design. At the same time, it should increase delegation to teaching quality guarantee system, in order to provide sufficient space for carrying out the targeted and creative teaching quality assurance work. 


\section{Conclusion}

The internal teaching quality guarantee system is the foundation of the quality assurance system of China-Germany cooperative education program. The basic elements of our internal teaching quality guarantee system of China-Germany cooperative education program include teachers, students, curriculum, teaching management, etc. On the basis of these factors, this paper discusses the basic path of teaching quality guarantee system in our school.

\section{Acknowledgment}

The authors gratefully acknowledge the financial support for this work provided by the Program of the teaching reform program for Chinese and foreign cooperation of Hubei University of science and technology, No.2017-ZYA-002, the Natural Science Foundation of Hubei Province, Grant No. 2016CFB515, the humanities and social science project of Hubei education department, No. 16Q259 and 18Q164, the National Natural Science Foundation of China (NSFC) under the Grant No. 61575148, the Dr. Start-up fund of Hubei University of science and technology No. BK1524,the colleges and universities of Hubei Province innovation and entrepreneurship training plan, No.201710927006Z, the Team Plans Program of the Outstanding Young Science and Technology Innovation of Colleges and Universities in Hubei Province, Grant No. T201817.

\section{Reference}

[1] He Zubin. The Establishment of long-term Mechanism of Teaching quality Assurance in Colleges and Universities in the period of Post-evaluation [J]. Chinese university teaching 3: 69-71.

[2] Lin Jinhui. Sino-foreign Cooperation in running Schools: policy, Management and quality Assurance [M]. Xiamen: Xiamen University Press: preface II.

[3] Jin Deng Zhou, Xiao Dan Wang, Heng Song. Research on The Unbiased Probability Estimation of Error-correcting Output Coding[J]. Pattern Recognition, 2011, (44):1552-1565.

[4] Lee Y. , Lee C. K. Classification of Multiple Cancer Types by Multicategory Support Vector Machines using Gene Expression Data[J].Bioinformatics, 2013, (18): 1132-1139.

[5] Helfat C. E., Eisenhardt K. M.. Inter-temporal Economics of Scope, Organizational Modularity and The Dynamic of Diversification[J]. Stratgic Management Journal, 2017, 25:1217-1232.

[6] Tension, etc., from a strategic perspective to study Sino-foreign cooperation in running schools, Shanghai Education, 200510B)

[7] Zhou Baihua, Exploration and reflection on Sino-foreign Cooperation in higher Education, Journal of Nanjing University of Technology (Social Science Edition ,2016( 4)

[8] Jin Xiaobai, Chinese-foreign cooperation in running schools and opening up of chinaundefineds education service industry. International business research 2013 (6) 